Surveyor

\title{
Surveying Experiences at the War
}

\section{H.G. Tolley}

To cite this article: H.G. Tolley (1919) Surveying Experiences at the War, Surveyor, 32:5, 109-118, DOI: $10.1080 / 18324460.1919 .10439485$

To link to this article: http://dx.doi.org/10.1080/18324460.1919.10439485

曲 Published online: 01 Aug 2012.

Submit your article to this journal

LII Article views: 3

Q View related articles $₫$ 
Harold Charles De Low, Clarence James Lyle West. John Leighton Aitken, Frederick William Buckhorn, Kenneth Robert Marshall Stretch, Oswald Watson, Henry Ernest Wansbrough, Frank Blake Humphries (all returned soldiers), and (reorge Wesley Vincent.

Eight candidates also completed their examination and have been recommended for appointment as I.icensed Surveyors, viz. :Raymond Thomas Hanks, 'Charles William Rhores, Geoffrey Ansell Robin, Darrell Wallace Isaacs, Percy Elston Raymond, Clifford George Roberts, James Thomas Stephens Ryan (all returned soldiers), and Henry Baxendale.

This is the largest number of successful candidates since October, I9I2, when 22 candidates were successful.

At a Council Mleeting held on 21st November a discussion was held on the points raised in Mr. Cardew s paper on "The Training of Surveyors as Engineers." The discussion was adjourned to a future date. Several suggestions $w^{r}$ re made, one heing that the Institution should issue a full diploma for Surveving, based on a separate examination in all branches of the profession. This would be held in addition to the L.S., which would stand as at present. Another suggestion was that the L.S. examination be varied by substituting for the present unsatisfactory Earthworks paper a paper in the general principles of Engineering as applied to Surveying, to include elementary hydraulics, road location and construction and preparation of specifications for road and drainage work.

The opinion was expressed that it would be a great assistance to the Council if members, particularly country members, would submit their views on this important subject, in writing, for publication. We print in this issue a contribution on the subject by Major H. G. Tolley, C.E., L.S.

\title{
SURVEYING EXPERIENCES AT THE WAR.
}

\author{
Read before the Institution of Surveyors. N.S.W., by MAJOR H. G. \\ Tolley, D.S.O., on Tuesday. 28th October, I9I9. \\ KITCHENER'S ()RDFRS.
}

Just prior to the evacuation of Gallipoli, Lord Kitchener paid a hasty visit to the Suez Canal defences, and found that the forces stationed there were letting the Canal protect them, instead of them protecting the Canal. Had the Turks attacked, or even made raids on the Canal, shipping would have been held up. With the prospective evacuation of Gallipoli, Kitchener considered it more than likely that the Turks would once more mass for attack on Egypt, so he gave orders for a strong line of defence to be pushed out into the Sinai Peninsular. All the remaining surveyors in the Egyptian service 
were given R.E. commissions, and sent out with camels and their native chainmen to make topographical surveys, whilst an Indian Cavalry Division patrolled the front.

\section{SinaI SuRvey.}

Kitchener had surveyed all this country many years previously and established minor triangulation stations on the few permanent hillocks there were. He had been careful not to contour the sand dunes, but had roughly located them. We found that many of the dunes had shifted miles, and during our brief occupation we noticed great movements in these dunes. Adopting the Kitchener trig. stations, the Egyptian surveyors, using large plane-tables with aluminium telescopes fitted with stadia wires, and vertical arcs, made a 5-metre survey, including the dunes. It was rather a novel sight to see the native staffmen riding around on camels and holding the staves without troubling to dismount.

\section{Sinai Defences.}

In the meanwhile, it fell to my lot to select part of the main line of defence. Higher authorities were very divided in opinions as to whether we should locate the trenches on the forward or reverse slopes. Ultimately we compromised. As most of the line was in the dunes, we had to revet with hurdles and sand bags, and, to get a trench $4 \mathrm{ft}$. $6 \mathrm{in}$. deep and $2 \mathrm{ft}$. wide at the bottom, we had to scoop out a hole $\mathrm{I} 6 \mathrm{ft}$. wide at the top and then backfill behind the hurdles. Just as we were priding ourselves on the strength of our fortifications, a great sandstorm arose, and when it abated we found our revetments on the forward slopes, standing high above the sand, whilst those on the reverse slope were hopelessly buried. Fortunately for us, we were hustled off to France, and left the mounted divisions to solve the problem of defence.

\section{THE NURSERY.}

We were first put in the line around Ploegstreet and Messines, this part being known as the Nursery, as it seemed to be an understood thing between both sides that raw divisions should be trained there, and when a shell burst it was usual for men to rush into No Man's Land in search for the nose-cap. The Huns got very annoyed when we sniped anyone who exposed himself. Then we started nightly raids and silenced many a Hun with a tap on the head with a knobkerri made of a hickory handle and a $4 \mathrm{lb}$. cogwheel on the end. Naturally, the Hun retaliated with crumps, and we would receive urgent messages to proceed to certain spots and repair damaged trenches. The locations given us were hardly ever right, and we soon learnt that hardly an officer or N.C.O. could read a map, still less fix a position by observing to two well-known land marks, so in the ten days' rest we had, prior to the Somme struggle, we spent at least eight hours daily instructing classes of Officers and N.C.Os. The greatest difficulty was to explain the magnetic variation. 


\section{Poziere Surveys.}

Then we got into the Pozieres battle. At that time the Hun had just produced the Fokker plane, which was so much speedier and more reliable than ours, that we lost the supremacy of the air, and consequently secured very few aerial photos. to help us, so we were dependent on ground surveys to locate our trenches. Owing to the great number of road intersections and ruined churches, we were able to get many sighting points, but shelling was so terrific that it took some determination to remove one's steel helmet to read the compass. In the front line it was necessary to select a little camouflage to sight through, as snipers were very alert. Trenches were so blown about that in renewing them we frequently shifted them roo to I50 yards and re-dug them daily to avoid the heaviest shelled areas. This entailed constant survey work.

\section{Compass Traverses.}

Each morning one of us proceeded along the trenches whilst a sapper held a pick handle above the trench some distance ahead. Often 1 would be just ready to read the bearing and estimate the distance, when the pick handle would diappear and debris would fly all over the place. One day it was particularly urgent that we should get a plot of the trenches, in order to erect position boards for the assembling of troops that night for an attack. Fritz was very attentive, and, after several narrow escapes, I was very worried, as my pick handle man failed to hoist the handle. On working around the trench, I found him looking rather white, and ruefully examining the pick handle, as it had been shattered by two shell splinters. On asking him what was the trouble, he replied: "Will I have to pay for this $b$ - thing, because I'm ten bob overdrawn." We eventually completed the traverse, and I was agreeably surprised to find that in a four miles close I was only 40 yards out, which was more by good luck than good management. We did more compass surveys in the Somme ' 16 struggle than at any time subsequently, for by the end of the year we had the air supremacy again, and never lost it, so were able to get aerial photos.

\section{Camera Lenses.}

I might mention that a fortunate accident gave the British the secret by which the Huns were able to manufacture lenses for all optical instruments, which were so superior to ours. A lady in London bought an expensive camera with Hun lenses, just before the war commenced, and promptly began to haul it to bits to see what was inside. Imagine her indignation when, on unscrewing the lens, it fell to bits. She immediately went back to the shop from which she had purchased the camera and was fortunately met by a man who had spent years trying to solve the Hun secret. He saw immediately that the Huns, in assembling the lens, had omitted to cement the component parts together. He tendered his most profuse apologies to the lady, and placarded her by presenting her with a more expensive camera. When the war broke out, he consulted the IVar Office 
$r e$ his discovery, and unlimited men, money and apparati were placed at his disposal for experimental purposes. Success was soon attained, and not only was a suitable invisible cement discovered, but materials were also found which made better glass than the Hun's. I had the pleasure, in I9I 7 , of testing the lenses side by side with the best Hun makes, and found that ours gave a clearer definition. A factory was erected, and by the middle of I9I 8 many of our aèro cameras were fitted with the new lenses, and our photos. were infinitely superior to those of the Hun.

\section{DEEP DUG-OUTS.}

During the Somme 'I6 struggle we captured many deep dug-outs, and were so impressed with them that everybody wanted more made, so that when we returned to the Somme, towards the end of the year, the Engineers were deluged with demands for dug-outs from every unit. We had great difficulty in securing suitable instruments for setting them out, but succeeded at last in getting box sextants and Abney levels. We were offered theodolites and plane-tables. Had the authorities, who offered us the instruments, been a little more junior in rank, we would have asked them to come along and demonstrate how to assume the prone position in a fifth of a second, whilst carrying these instruments, without damage either to ourselves or the instruments. We put the shafts down on a I to I slope, close setting the timber for $6 \mathrm{ft}$. in depth, and then spacing according to the soil until we obtained $20 \mathrm{ft}$. of cover. Working continuous shifts this usually took four days. The shafts were always sunk in pairs $20 \mathrm{ft}$. to $40 \mathrm{ft}$. apart, and galleries $6 \mathrm{ft}$. wide and $6 \mathrm{ft}$. $6 \mathrm{in}$. high, driven to connect them. Three tier bunks $6 \mathrm{ft}$. long were erected on each side of the galleries, and chambers were driven off the foot of the shafts to accommodate the C.Os. and telephone staffs.

\section{lí.ining CoMpany.}

As the weather varied from $10^{\circ}$ to $30^{\circ}$ below freezing point, there was an immense demand for dug-outs, as they were comparatively warm to live in. The brigade we were working for was so impatient at our apparently slow progress that it formed a so-called mining company. The men were mostly chaps who thought it would be a "cushy", job and had no mining knowledge, and the officers had no instruments, and probably could not have used them if they had. Dug-outs without timbering, and with only a few feet of cover, were put in, which proved veritable death-traps. Galleries seldom met, and, as men crowded in to them for warmth, as the work progressed the air got so poisonous that candles would scarcely burn. Then falls of earth caused casualties, and in due time the mining company was handed over to us to supply the labour for removing the spoil. Some of the dug-outs were made to accommodate 250 men, besides medical aid posts, and a warming chamber, where batches of men from the front line would be sent to thaw out and change into dry clean socks, and get piping-hot soup and cocoa made on primus stoves. 


\section{SuRvey CoMpanies.}

About this time Survey Companies were formed to do battery spotting for the artillery. Reinforced concrete observation posts were established along the whole battle front, one to three miles in rear of the front line. They were most accurately located, and observing marks were erected with a known azimuth. Telescopes were mounted on horizontal graduated plates, and each post was connected to the Survey Company's H.Qs. by telephone and by an electrical button arrangement, which, on being pressed, lighted a bulb on the H.Q's. switchboard. The observers worked mostly at night, and spotted the highest point of the arc of flash from enemy guns. Three posts would be detailed to observe for guns in a certain map square. When they observed, they pressed the button and H.Qs. would know, if three bulbs flashed at once, that the observers were probably on to the same gun or battery, and would telephone O.K. The observers would then telephone back their bearings, and the three rays would be plotted. Should they not agree very closely, observers would be instructed to observe again. Of course, it was impossible to observe when heary shelling was going on, but the Hun had a pleasant habit of keeping us awake by continual fire from one or more guns. Each morning the division artillery would get a report as to the position of guns located ; then, should a battalion commander call for retaliatory fire, Fritz gunners used to get some hurry up. We found, from that time onwards, the morale of the enemy gunners went down and consequently their accuracy.

\section{Spring, I9I7, AdvancF.}

In the Spring, I9I7, advance, our time was wholly occupied in removing booby traps and mines from roads, dug-outs, cellars and wells, and in pushing forward communications. One of our companies made its temporary H.Qs. in the cellars of the Bapaume Town Hall, and three of its officers were sleeping there, after three days and nights of continuous toil, when the place went up. So sleepy were they, that the explosion didn't disturb them sufficiently to get up and investigate, but I2 hours later one of them got up and found the cellar entrance blocked, and was astonished to hear picks at work above. We toiled ceaselessly for 24 hours, and out of the roo odd officers and men quartered in the Town Hall, those three were the only men taken out alive.

In one case we examined a set of cellars in which one of our brigade headquarters was living, and took out several mines, each of which would have blown the occupants to atoms. It was nerveracking work, but we were fortunate in not suffering a single casualty.

\section{Messines Preparations.}

After the disastrous attack on the Hindenburg line at Riencourt, in which our division was nearly wiped out, and Captain Waine, of this Institution, had the misfortune to be taken prisoner, we were sent to the $\dot{M}$ essines sector to prepare for that stunt. It was a most thorough preparation. Our task was to build shell-proof command posts at 
each of the siege batteries, and light railways to them. We had the satisfaction of seeing two of these posts well and truly tested by Hun shells. In each case the occupants were badly stunned, and bled at the ears from the concussion, but the structures stood up to the shells.

Messines was the first battle in which all arms were thoroughly co-ordinated. Each arm prepared maps showing exactly what it was proposing to do, and then we met and thrashed out each point, made a general plan of operations, and then issued our own orders for the stunt, which consisted of providing roadways, bridges, tramways, water supply, dumps of materials, reconnoitring the captured area, selecting sites for support and reserve lines and digging strongpoints thereon, and pushing out entanglements. Gradually we found that we Engineering Company Commanders were expected to attend all Brigade Conferences and submit works policies.

\section{Messines Experiences.}

The C.R.E. of our division and myself had rather an unlooked for experience in this battle, whilst on reconnaissance. A slightly-wounded Hun ran into us, and started to cry in a most pitiful voice " Kamerad," and held his hands up. We tried to explain to him to proceed down a certain track to our rear lines, but the more we tried to explain the louder he " Kameraded," so we piloted him over to a large pill-box, with the idea of sending a stetcher-bearer to collect him. Outside the pill-box there were 25 Huns, most horribly mangled, one of our shells having burst apparently right on top of them. Going into the pill-box we found the whole staff of a Hun battalion and the 'phone to their Division Headquarters still intact. Our boys, in the assault, having seen all the dead outside, had evidently thought that the pill-box had been mopped up. Besides a good bunch of prisoners, we secured a fine lot of maps and souvenirs, including the telephone, all of which one of the prisoners was good enough to carry for us.

\section{YPRES Battles.}

Then came the Ypres Salient battles, under the most fearful conditions of the war. The country was an absolute quagmire, under direct observation of the Hun. Our job was to push up plank roads for the artillery, mule mats for the pack mules, and duckboard tracks, supported on trestles, for the troops. It was quite impossible to make trenches or dug-outs, and most of the pill-boxes had been smashed. Those remaining were such conspicuous targets to the enemy that it was safer to keep away from them. We used one as a H.Qs., but got three direct hits on top of it in one night, which made us all very groggy, so we abandoned it. Our advanced parties on the duckboard tracks were shelled, bombed and machine-gunned, both from the ground and the air, and water in the shellholes was often so impregnated with mustard gas that, if anyone slipped into them, great yellow blisters the size of turkey eggs came up on their legs. The men had to exist in mud and slush everywhere. Whenever an unbiassed history of the war is written, I am sure that General Haig will be most scathingly 
censured for sacrificing the flower of his army in capturing the quagmire called Passchendaele Ridge, for it was of little tactical value when we did get it.

\section{Morale of Troops.}

The morale of the troops was never at a lower ebb than when they came out of that sector, and many of the British divisions had not recuperated by the time of the Hun offensive in March, I9I8, and simply ran for their lives, many of them hardly firing a shot.

\section{I9I8 Hun OfFensive.}

The I9I7-I8 winter found us, first on the Cambrai front and then on the Hill 60 sector, busily fortifying against the Hun offensive, which everyone was predicting for March. We were relieved a week before it was launched, but one of the other Aussie divisions, in a successful raid, captured secret papers which gave the date and front on which the attack was to be launched. This information was circulated to the divisions on the front concerned, yet many of them were surprised. As soon as the Huns broke through we were pushed down S. to our old familiar haunts on the Somme, and ceased to function for a time as Engineers, going into the line as infantry.

\section{REFUGEES FROM HebUteRne.}

Never have I seen such a heart-breaking sight as that which met our eyes as we approached Hebuterne. Poor old men and women, bent with age, and hungry, footsore children, hobbled painfully through the suffocating dust, carrying Cavalrys or Madonnas and little bundles of valuables, and leading a few cows and horses, whilst a khaki-rabble, minus arms and accoutrements, hustled past, and never offered the slightest assistance. Our men's faces were a study. Covered in the light grey dust, with streaks of perspiration pouring down their faces, some grinding their teeth with rage, others almost crying with pity for the refugees, it boded ill for the enemy. But you know what happened in those next few critical weeks, so I shall hasten on.

\section{SoMme, IgI8.}

We soon had a little breathing space, and resumed our normal work, laying out trenches and wiring them, building bridges, and making dummy bridges and approaches out of painted canvas, in conspicuous places, on which the Hun wasted tons of ammunition. Besides that, we launched out on a great amount of dug-out accommodation, especially for dressing stations, as night bombing was getting very severe, and for a poor unfortunate, too weak to leave his bed to seek safety, it was a fearful ordeal to hear the Hun planes and wonder where the next bomb would drop. 


\section{HAMEL STUnT.}

Then came the time when General Monash advised G.H.Qs. that, given another good Corps, we could smash the Huns, and, to demonstrate our ability to do so, the Hamel stunt was planned as a miniature rehearsal for the great offensive. You will see in the maps and photos. that I have on exhibition, the work that fell to our lot. The careful survev of our defences, the minute reconnaissance of the enemy area by means of direct and balloon observation and aerial photography, enabled us to get out a map showing exactly what we proposed to do, and it was carried out to the letter.

\section{The AMirericans.}

We had Americans attached to us for instruction, and they caused us much amusement. First of all they complained bitterly of our rations, especially the tea. On investigation, we found that their cooks were putting the tea into cold water and boiling it up. Their supply arrangements were chaotic in the line. We found that some of the men had not received any rations for 36 hours, so the General went over to interview their C.O. On telling him of our discovery, he replied: "Look here, General, I guess I'm fighting the biggest fight ever, and I've got no time to think of those here rations." Souvenirs were plentiful in the Hamel stunt, and a Yank was displaying a fine gold watch, which he had been made a present of by a Hun, to some of our diggers, one of whom remarked: "By Jove! Yank, you'll get into a devil of a row if any officer sees you with that. It's against all regulations to stick to souvenirs. I've been appointed to collect all these watches and hand them in." At the same time he pulled out a handful of watches he had taken from Hun prisoners, and the Yank was so impressed that he handed his watch over. Later on he had doubts, so went to one of my officers for advice, and was told that he had been a mug. He said : "Wall, I guess I'll know that guy again when I see him, and, Allie or no Allie, I guess I'll not be friendly like."

\section{August OfFENSIVE.}

With the great August offensive, we were more than fully occupied in reconnoitring, examining dug-outs for booby traps, and driving gas out of them, as the Huns had thrown glass capsules of mustard and lachrymatory gas down many of them. Besides that, we had to repair wells and hauling gear and test the water. We found that many of them had been fouled with organic matter, but in no cases did we find poisons. A water-testing outfit was part of our equipment.

Our aerial and balloon service was so splendid, that surveys, except to locate dug-outs, were no further required. We were kept well supplied with oblique photos. taken from captive balloons, and vertical photos. from the planes, similar to those which I have on view.

\section{RECONNAISSANCE OF BelgiUm.}

When we advanced after the Armistice into Belgium, towards the Luxemburg frontier, we had a very busy time in moving mines 
from under the main roads and filling in craters where the mines had already exploded, besides compiling maps showing everything of value for war purposes. Some of us also had the opportunity of examining the waterways of Germany, Alsace-I.orraine and Eastern Belgium. From an engineering point of view, it was the most interesting and useful time I had at the war.

\section{MAPS AND SURVEYORS.}

You will see that all our maps were plotted to a natural scale, and most of our topographical maps were very accurate. There was always a lot of map work to be done, especially for stunts, but it was a great difficulty to maintain an efficient survey section, for surveyors, having such a grasp of the value of terrain for offence or defence, also a bump of locality, night or day, and experience in handling men, made splendid officers, and, once they attained commissioned rank, their time was so fully taken up looking after their men and works, that their services were lost to the survey section. I don't think any men-are more fitted for officers than surveyors, and yet hardly any of them were given commissions, to commence with. We may well take pride in the fact that so many rose from the ranks and acquitted themselves so well.

\section{WHO WON THE WAR?}

In conclusion, Mr. President and gentlemen, allow me to digress a little further, and ask you who won the war? The Italians claim the honour, and point to the fact that they saved the French and British on the Western Front and in Macedonia. The Belgians are equally positive, that by delaying the Huns in front of Liege, they saved civilisation. They don't mention that their magnificent defence throughout the war cost them less in casualties, including men, women and children, than any one of our divisions in France. No doubt the Portuguese are not hiding their light under the bushel, whilst the Yanks not only won the war, but taught us how to do it. I believe a few of our returned men also state that given another Corps, we could have wiped Fritz off the earth without any outside assistance.

\section{TRIBUTE TO THE FRENCH.}

Where do the French come in? Do you realise that they have lost one-third of their able-bodied men in killed and maimed alone? Do you also realise that, in spite of overwhelming odds in men and guns against them they were the only nation in the war who didn't have a single division break from the front line. They were compelled to retire in 1918 on Soissons and Chateau Thierry, because the British, who had not recovered their morale after the retreat further north, broke in the centre. Why, it made a man's blood tingle to see the Chasseurs, and many another famous French regiment, advance to battle. There was such energy in their short quick step, and such determination in their faces, as would inspire any one. Proud as we diggers are of our Corps, we must admit that at our very best we were no better than the French. The Huns will tell you so, and they 
ought to know. Yes! we may well take our hats off to the French. And yet, through those terrible four-and-a-half years, not an acre in the uninvaded area was allowed to go out of cultivation. The women toiled in all weathers, from dawn to well into the night. Still, they always had a happy greeting for us, and a hot cup of coffee, no matter what the hour. I shall always love France and its people, and think that verse which Kipling has composed, in his inimitable style, is only too true.

"Broke to every known mischance; leaping over all.

By the light sane joy of life; the Buckler of the Gaul,

Furious in luxury; merciless in toil ;

Terrible in a strength renewed from a tireless soil.

Strictest judge of her own worth ; gentlest in man's mind.

First to face the truth, and last to leave the old truths behind.

France! beloved of every soul that loves, or serves its kind."

\section{Some Candidates' War Experiences.}

F. W. BuckhorN enlisted in the Field Artillery Reinforcements, in Feb., 'I7. Served in France as a gunner with the Heavy Trench Mortar Battery, and participated in the taking of Hamel (July 4 th), and in the advance from Villers Brettonneux on Aug. 8th.

He was afterwards attached to the 2nd Battery, Ist F.A.I3., and took part in the attack on the Hindenburg line. Returned to Australia with Survey School on Aug. 2oth.

C. J. L. WFST, enlisted Aug., IgI6, as gunner in Field Artillery. Sailed trom Sydney, December, I9I6, as Acting-Sergeant, and joined I2th Army Brigade Aust. Field Artillery at Nieuport, in Belgium, July, I9I7. Served continuously in France and Belgium with the Brigade until March, I9I9. Main engagements :-Ypres, Passchaendaele, Arras, Robecq, Strazeele, Merris, and Somme advance on and after 8th August, I9I9, up till the Armistice. Promoted Sergeant Ist Feb., IgI8.

Lance-Corporal J. L. AJTkIN enlisted on 3rd Oct., I9I6, as a sapper in the Engineers. Sailed from Sydney on Ioth Feb., I9I7, and joined the 6th Field Company Engineers in June, r9r7, and served continuously with that Company till March, I9I9. Was with that Company in the battles of Menin Road and Jonnebeke, and was made Lance-Corporal in December, I9I7. In many minor engagements leading up to advance of August, I9I8, and with the Company in that advance and engagements following it. Arrived back in Sydney, 2oth August, Igrg. 